\title{
Geology of the Breitenbush River Area, Linn and Marion Counties, Oregon
}

By George R. Priest, Neil M. Woller, and Mark L. Ferns,

Oregon Department of Geology and Mineral Industries

\section{Structural Geology}

The area is cut by a major N. $22^{\circ} \mathrm{E}$-trending fault that is here referred to as the "Hoover fault" for its exposure on the east end of Hoover Ridge. The Hoover fault separates northwest-tilted rocks of unit Tbl on Hoover Ridge from younger rocks east of the fault. The youngest rock cut by the fault is unit Tbu, where it is interbedded with unit Ts. No ages are available for the lower part of unit Tbu. Interbedded lavas of unit Ts have a minimum age of 19.4 million years (Ma) (White, 1980a,b; Fiebelkorn and others, 1982). The total down-to-the-southeast off'set across the Hoover fault is unknown, but unit Tbq is about $300 \mathrm{~m}$ higher in elevation on the northwest side of the fault than on the southeast side between Beard Saddle (outside of the map boundary) and Tom Creek. Unit Thq apparently dips toward the southeast at Tom Creek, so the net slip is probably smaller than the difference in elevation. The Tom Creek area is the only place where the same unit has been found on both sides of the Hoover fault. The fault mapped at Tom Creek is very close to the edge of the map, 80 more faulting could be present west of the map boundary. It may be that the fault has lesser net slip in the Tom Creek area than in areas to the north. It is also possible that there is an angular unconformity between units Tbq and Tbl. Dips in unit Tbl near Stahlman Point (west of the map boundary near Beard Saddle) are toward the northwest, whereas overlying rocks of units Ts and Tbq appear to have subhorizontal dips. This discordance in dips suggests that a period of deformation and erosion preceded unit Tbq. Therefore, some deformation could have occurred on the Hoover fault prior to unit Tbq time that would not be detectable as offsets of unit Tbq. Additional mapping in the Stahlman Point-Beard Saddle area is critical to resolution of this problem.

Rocks on the east block of the Hoover fault have mostly subhorizontal or gentle southeasterly to southwesterly dips, unless they have been deformed adjacent to the Hoover fault. Numerous small faults tilt the east-block rocks on the western margin of Boulder Ridge. The largest block is tilted towand the northwest in the Cliffs Creek area. This local fault block is separated on its southeast side from the rest of the east-block rocks by a northeast-trending subsidiary fault that is exposed on the ridge separating Cliffs and Cultus Creeks. The exposed fault plane strikes N. $35^{\circ} \mathrm{E}$., dips $63^{\circ}$ to the southeast, and has slickensides raking $23^{\circ}$ to the southwest. Unit Tbq is locally offset a maximum of about $240 \mathrm{~m}$ down toward the northwest across the fault. If the exposed slickensides and dip are representative of the direction of net slip and the attitude.on the entire fault zone, then the fault is a high-angle reverse fault with left-lateral oblique slip. However, the irregular trace of the fault across the topography offers no support for the easterly dip or for a large component of strike-slip movement. If the irregular trace of the fault reflects a local irregularity in the fault plane, then this may not be relevant to the fault as a whole. The northwest-tilted sequence is separated from gently dipping east-block rocks to the northwest by an inferred fault that roughly follows the Breitenbush River Stratigraphic offset across this inferred fault is difficult to estimate but is probably small, with the northwest side down. The northwest-tilted block thus appears to be a northeast-trending monoclinal flexure that has been broken at the flexure points. The net result is that the rocks northwest of the flexure are displaced downward relative to rocks southeast of the flexure. The flexure could be the result of secondary folding caused by a small component of left-lateral shear on the Hoover fault.
Although there is no evidence of large-scale compressional folding, the northwesterly dip of the rocks on the northwest side of the Hoover fault at Hoover Ridge and the southwest to southeast dip of rocks on the southeast side of the fault on Boulder Ridge can be interpreted to form a faulted anticlinal structure (see descriptions of the Breitenbush anticline by Thayer, 1939). The fact that the fold axis is coincident with faults introduces other possible interpretations. The southwestward dip of unit Tbq along Boulder Creek could be the southwestward-plunging nose of this anticline. However, if, as suggested above, units Tbq and Tbl are separated by an angular unconformity, then dips on the east block measured in unit Tbq and younger units may have little or no relationship to dips of unit Tbl on the west block of the Hoover fault. Even dips measured in rocks mapped as unit Thl on the southeast block are not necessarily helpful, because it is not known with certainty whether unit Thl on the southeast block is correlative to or even approximately contemporaneous with unit Tbl on the northwest block of the Hoover fault. It is passible that some northwestward-dipping rocks of unit Tbl lie beneath the southeast-block rocks mapped as unit Tbl and are separated from them by an angular unconformity. The "anticline" would, in that case, be an artifact of the faulting. The relatively high dip of the older rocks on the northwest block relative to the younger rocks of the east block and the abrupt change of dip across the Hoover fault support this interpretation.

If a marker unit contemporaneous with unit Tbl could be correlated across the Hoover fault, this would lend credence to the concept of an anticline. It would also help to establish the amount of offset that may have occurred before deposition of unit Tbq. For example, if unit Tls, which is conformable on top of northwesterly dipping rocks of unit $\mathrm{Tbl}$ at the mouth of the Breitenbush River (west of the map boundary), could be located on the southeast block, this would suggest that the sequence was folded. Drilling to $2.5 \mathrm{~km}$ on the southeast block (Sunedco Well No. 58-28) has failed to intercept either the unit Tls sequence or any other pre-Tbq unit that can be correlated across the Hoover fault. The unit Tbl sequence intercepted in Sunedco Well No. 58-28 appears to have a greater quantity of ash-flow tuff than is typical of unit Thl cropping out on the northwest block. A highly altered, quartz-rich tuff intercepted in the lower part of the well is also not known to crop out anywhere on the northwest block. It is possible either that, owing to accidents of original rock distribution, no distinctive units correlate across the fault, or that dip-slip offset on the Hoover fault prior to the deposition of unit Tbq could be so large that the bottom of the $2.5-\mathrm{km}$-deep well is in units younger than any Tbl or Tls units that crop out on the northwest block of the fault. This amount of dip-slip would require an offset in excess of $4 \mathrm{~km}$. This latter possibility could be tested either by deepening Sunedco Well No. 58-28 to see if unit Tls can be intercepted or by attempting to correlate the distinctive quartz-rich tuff from the lower part of the well to outcrops outside of the map area on the northwest block of the Hoover fault. If this extreme dip-slip offset is present, then the quartz-rich tuff should crop out somewhere above the unit Tls sequence on the northwest block.

Aside from some small-displacement, northwest-trending normal faults in the Outerson Mountain area (Clayton, 1976; Rollins, 1976); the only other major deformation in the map area is a northeast-trending fault, named the "Bruno fault," which crops out in a roadcut on the northeast flank of Mount Bruno. The Bruno fault strikes N. $30^{\circ} \mathrm{E}$. and dips $80^{\circ}$ to the southeast. The 


\section{DISCLAIMER}

This report was prepared as an account of work sponsored by an agency of the United States Government. Neither the United States Government nor any agency Thereof, nor any of their employees, makes any warranty, express or implied, or assumes any legal liability or responsibility for the accuracy, completeness, or usefulness of any information, apparatus, product, or process disclosed, or represents that its use would not infringe privately owned rights. Reference herein to any specific commercial product, process, or service by trade name, trademark, manufacturer, or otherwise does not necessarily constitute or imply its endorsement, recommendation, or favoring by the United States Government or any agency thereof. The views and opinions of authors expressed herein do not necessarily state or reflect those of the United States Government or any agency thereof. 


\section{DISCLAIMER}

Portions of this document may be illegible in electronic image products. Images are produced from the best available original document. 
fault at the outcrop juxtaposes units Tmd and Tmb and is therefore younger than about $10 \mathrm{Ma}$. A flow of unit Tp dated at $6.1 \mathrm{Ma}$ occurs on the southeast side of the Bruno fault on the southeast flank of Mount Bruno, but owing to the local lithologic similarity of units Tmb and Tp, it is not known for certain if the fault cuts unit $\mathbf{T p}$ there. Unit $\mathbf{T} p$ is apparently offset down to the east across the fault near Bruno Creek, although the palagonite-rich character of unit $\mathbf{T p}$ on the east side of the fault versus the paucity of palagonite tuff in unit $T p$ west of the fault casts some doubt on the correlation. Down-to-the-east offset is also suggested by the increasing southeasterly dip of volcaniclastic interbeds in unit $\mathbf{T} \mathbf{p}$ as the postulated extension of the fault is approached from the east. These southeasterly dips could be caused by drag. If the palagonite-rich rocks on the east side of the projected fault are unit $\mathbf{T} \mathbf{p}$, then there is dip-slip offset of about $370 \mathrm{~m}$ across the fault. The unit Tp sequence adjacent to the fault at Bruno Creek crops out at Bachelor Mountain, where the uppermost flow has a $\mathrm{K}$-Ar age of 6.35 Ma. Unit Tub appears to thicken abruptly across the southwestward extension of the fault, suggesting that unit Tub is lapping onto an east-facing fault-line scarp. The base of unit Tub has $\mathrm{K}$-Ar ages of 2.7 to $3.1 \mathrm{Ma}$, so the fault was active prior to about $3.1 \mathrm{Ma}$. The fault was therefore probably active sometime between 3.1 and $6.35 \mathrm{Ma}$.

The down-to-the-east offset and age of the Bruno fault are similar to ages and offsets inferred for faults bounding the west side of a regional graben in the High Cascades of central Oregon (Allen, 1966; Taylor, 1980). However, the N. $30^{\circ} \mathrm{E}$. strike of the fault where it crops out does not match the nearly north-south trend of the postulated graben faulting. The fault is also west of the North Santiam River, not at the river, as inferred by Allen (1966). It is possible that the fault extends to the northeast through Woodpecker Ridge and the Sentinel Hills, where it is obscured by younger lavas. This extension cannot be proved with available stratigraphic information. The fault also apparently extends southward where it merges with a zone of down-to-the-east faulting with a more northerly trend (Black and others, 1987).

\section{Mineralization}

Samples from most of the intense alteration zones were analyzed for a broad spectrum of ore metals. Only one sample had a metal content above background levels. The sample came from a quartz-veined shear zone in a tuffaceous debris flow of unit $\mathbf{T b}$ at Hoover Ridge. The shear zone trends $\mathrm{N}$. $55^{\circ} \mathrm{W}$. and dips $82^{\circ}$ to the northeast with horizontal slickensides. Drusy quartz with open boxworks containing abundant iron oxide was sampled. Two batches of quartz fragments were analyzed, both labeled NS-473. One sample has 57 parts per million (ppm) $\mathrm{Cu}, 1,394 \mathrm{ppm} \mathrm{Pb}, 10$ ppm $\mathrm{Zn}, 1 \mathrm{ppm} \mathrm{Mo}, 3.6 \mathrm{ppm} \mathrm{Ag}$, and $<5$ parts per billion (ppb) Au. The other sample has $175 \mathrm{ppm} \mathrm{Cu,} \mathrm{2,722} \mathrm{ppm} \mathrm{Pb}, 40 \mathrm{ppm} \mathrm{Zn,}<1$ ppm Mo, $8.6 \mathrm{ppm} \mathrm{Ag}$, and $35 \mathrm{ppb} \mathrm{Au}$. The analyses were performed by Chemex Labs L.td., North Vancouver, B.C., utilizing quantitative and semiquantitative multielement induction coupled plasma (ICP) analysis, except for Au, which was determined by fire assay/atomic absorption (AA). The sample location is in a roadcut at sec. 29 Dbacc, T. 9 S., R. 6. E., long $122^{\circ} 5^{\prime} 53^{\prime \prime}$ W., lat $44^{\circ} 45^{\prime} 44^{\prime \prime} \mathrm{N}$.

Walker and others (1985) found anomalous contents of metallic elements in rocks and stream sediments from the Battle Creek area and in rocks from the ridge immediately east of Dunlap Lake. The former area had rock samples with maximum values of $>20,000$ ppm Cu, 150 ppm Pb, 500 ppm Zn, 7 ppm Mo, 200 ppm Ag, and $350 \mathrm{ppb} \mathrm{Au}$. The latter area had rock samples with maximum values of $20 \mathrm{ppm} \mathrm{Cu}, 20 \mathrm{ppm} \mathrm{Pb},<200 \mathrm{ppm} \mathrm{Zn,} 20$ ppm Mo, $15 \mathrm{ppm}$ $\mathrm{Ag}$, and $150 \mathrm{ppb} \mathrm{Au}$. The analyses were obtained by semiquantitative spectrographic analysis. Walker and others (1985) concluded that these areas have moderate mineral potential.

\section{Geothermal Resources}

Thermal fluid has been encountered at two localities in the map area. Thermal fluid reaches the surface at Breitenbush Hot Springs, and a thermal aquifer was encountered in Sunedco Well No. 58-28 at a depth of 752 to $782 \mathrm{~m}$. The hot springs have a temperature of about $86^{\circ} \mathrm{C}$ (Mariner, 1985), with temperatures in adjacent shallow wells as high as $110^{\circ} \mathrm{C}$ at $100 \mathrm{~m}$ (Blackwell and others, 1981). The thermal aquifer in Sunedco Well No. 58-28 had a temperature of $136{ }^{\circ} \mathrm{C}$, when measured by a maximum-reading thermometer during drilling ( $A$. Waibel, unpublished data, 1982). A thermistor log run about six months after drilling measured a maximum temperature of about $115^{\circ} \mathrm{C}$ in the same part of the well (Blackwell and others, 1986). The second temperature reading was taken after the aquifer had been cemented off and cased. It is possible that injected cement and drilling fluid may have disturbed the natural flow of water in the aquifer enough to account for the discrepancy between the two temperature readings. The complete temperature-depth profile of Sunedco Well No. 58-28 is not available, but, from data in hand (A. Waibel, unpublished data, 1982; Blackwell and others, 1986), it is apparent that the thermal aquifer has raised the temperature gradient ahove regional background values (Priest, 1985). No stable temperature readings are available for the lower part of Sunedco Well No. 58-28, but the maximum recorded bottom-hole temperature of $141{ }^{\circ} \mathrm{C}$ (A. Waibel, unpublished data, 1982) is consistent with a minimum background gradient of about $56^{\circ} \mathrm{C} / \mathrm{km}$ (Priest, 1985). This gradient is consistent with gradients expected for sites in the Cascade heat-flow anomaly of Blackwell and others $(1978,1982)$ (Priest, 1985).

Thermal fluids in the area ocur in unit Ts near its lower contact with unit Tbq or in unit Tbq. The hot springs emerge from fractures in unit Ts near the contact with underlying unit Tbq. The thermal aquifer in Sunedco Well No. 58-28 is located in fractured and sheared tuff of unit Tbq near the contact with overlying unit Ts (see cross section). Anomalously high temperature gradients occur near the hot springs and near Sunedco Well No. 58-28. The gradients decrease gradually toward the east and fall off abruptly to background values a short distance to the west of the well (Blackwell and others, 1986). This is consistent with an easterly dipping heat source, probably the aquifer intercepted in the well (A. Waibel, personal communication, 1985). The dip of the Breitenbush Tuff in the area adjacent to the well is approximately $10^{\circ}$ to the east-southeast. The thermal fluid may thus be flowing upward along permeable zones in the tuff from sources under the High Cascades to the east. If the fluid cools by conduction and mixing with cooler fluids as it flows, then it may be significantly hotter to the east. Estimated reservoir temperatures for Breitenbush Hot Springs are $176{ }^{\circ} \mathrm{C}$ (sulfate-water method), $174{ }^{\circ} \mathrm{C}$ (anhydrite method), $166^{\circ} \mathrm{C}$ (quartz method), and $148{ }^{\circ} \mathrm{C}$ (Na-K-Ca method) (Mariner, 1985). The higher estimated temperature are probably most representative of the actual reservoir temperature (Mariner, 1985). The proposed geothermal model could be tested by drilling and sampling a $2-\mathrm{km}$ hole at sec. 36 Ddd, T. 9 S., R. 7. E.

\section{Analytical Procedures}

Approximately 165 whole-rock chemical analyses were utilized in the study to help define and characterize stratigraphic units and to search for economic minerals. These data will be presented in an open-file report to be published by the Oregon Department of Geology and Mineral Industries. The data were generated by atomic absorption - spectrophotometry, Christine McBirney, analyst, University of Oregon, and by quantitative and semiquantitative multielement ICP analysis at Chemex Labs, Ltd. Multiple splits of samples and previously analyzed samples were submitted to aid in quality control.

K-Ar data were generated by Robert Duncan, Oregon State University, Corvallis, Oregon, and Paul Damon, University of Arizona, Tucson, Arizona, utilizing standard methods. ${ }^{40} \mathrm{Ar} /{ }^{39} \mathrm{Ar}$ data were generated by Daniel Lux, University of Maine, Orono, Maine, utilizing standard methods. In some cases, where the radiometric dates were obviously in error (e.g., an older date stratigraphically above a younger date), the samples were rerun. In most cases, the dates were exactly the same in the second run, suggesting that the errors were not in the analysis but were in the assumption that the isotopic systems had been closed to $K$ and/or Ar exchange. 


\section{Acknowledgments}

The map was reviewed by Richard M. Conrey, Washington State University; Paul E. Hammond, Portland State University; David R. Sherrod, U.S. Geological Survey (USGS); and Norman S. MacLeod, Thomas P. Thayer, and George W. Walker, USGS, retired. Their comments and suggestions added greatly to the quality of the map. Britt Von Thaden, Rebecca A. Heisler, John Doerr, and Eileen L. Webb assisted in compilation and collection of the field and laboratory data. Gary Baxter supervised quality control on chemical data. Albert Waibel, Columbia Geoscience, provided in terpretations and unpublished logs of the geothermal well data released by Sunedco Energy and Development Company. Sunedco is to be congratulated for its efforts to help geothermal and geologic research in the area by releasing its data to the public. The United States Department of Energy provided partial support for the analytical work and field work.

Table 1. (See accompanying map.)

Table 2. ${ }^{40} \mathrm{Ar} /{ }^{39} \mathrm{Ar}$ data for samples from units $\mathrm{Tp}$ and $\mathrm{Tmb}$ in map area and from unit Tis in Hall Ridge area west of map area

\begin{tabular}{|c|c|c|c|c|c|c|c|c|c|c|c|c|c|c|c|c|}
\hline $\begin{array}{l}\text { Sample } \\
\text { no. }\end{array}$ & $\begin{array}{c}\text { Geologic } \\
\text { unit }\end{array}$ & $J$ & $\begin{array}{c}\text { Plateau } \\
\text { age } \\
(\mathrm{Ma} \pm 10)\end{array}$ & $\begin{array}{l}\text { Total fusion } \\
\text { age } \\
\text { (Ma) }\end{array}$ & $\begin{array}{c}\text { Temp. } \\
\text { ("C) }\end{array}$ & $\frac{{ }^{40} \mathrm{AC}}{{ }^{39} \mathrm{Ar}}$ & $\frac{{ }^{37} \mathrm{Ar}}{{ }^{39} \mathrm{Ar}}$ & $\frac{{ }^{36} \mathrm{Ar}}{{ }^{39} \mathrm{Ar}}$ & $\begin{array}{l}\text { Moles } \\
{ }^{39} \mathrm{Ar}\end{array}$ & $\begin{array}{l}{ }^{39} \mathrm{Ar} \\
(\%)\end{array}$ & $\begin{array}{l}{ }^{40} \mathrm{Ar}_{\text {sad }} \\
(\%)\end{array}$ & $\mathrm{K} / \mathrm{Ca}$ & $\begin{array}{l}\text { Apparent age } \\
\text { (Ma) }\end{array}$ & $\begin{array}{l}\text { Location } \\
\text { T.(S.)/A.(E.)/sec. }\end{array}$ & Latitude (N) & Longitude (W.) \\
\hline NS-462-W & $T p$ & 0.006097 & $6.10=0.91$ & 5.98 & $\begin{array}{r}865 \\
985 \\
1065 \\
1155 \\
\text { FUSE } \\
\text { Total }\end{array}$ & $\begin{array}{r}3.32 \\
2.86 \\
3.23 \\
4.65 \\
11.84\end{array}$ & $\begin{array}{r}2.4084 \\
7.9830 \\
10.7515 \\
18.9252 \\
\mathbf{3 4 . 1 4 9 4}\end{array}$ & $\begin{array}{l}0.0099 \\
0.0100 \\
0.0119 \\
0.0190 \\
0.0473\end{array}$ & $\begin{array}{r}505.3 \\
353.3 \\
173.1 \\
93.1 \\
44.6 \\
1169.4\end{array}$ & $\begin{array}{r}43.2 \\
30.2 \\
14.8 \\
8.0 \\
3.8 \\
100.0\end{array}$ & $\begin{array}{r}17.0 \\
17.6 \\
16.7 \\
11.5 \\
5.1\end{array}$ & $\begin{array}{l}0.2031 \\
0.0610 \\
0.0452 \\
0.0255 \\
0.0140\end{array}$ & $\begin{array}{l}6.21 \pm 0.16 \\
5.58 \pm 0.26 \\
5.96 \pm 0.66 \\
5.97 \pm 1.80 \\
6.77 \pm 2.67\end{array}$ & $11 / 7 / 4$ Bdbd & $44^{\circ} 39^{\prime} 00^{\prime \prime}$ & $121^{\circ} 57^{\prime} 23^{\prime \prime}$ \\
\hline NS-328-W & Tmb & 0.006077 & $6.45 \pm 0.46$ & $8.56^{-}$ & $\begin{array}{r}825 \\
925 \\
1000 \\
1075 \\
1145 \\
\text { FUSE } \\
\text { Total }\end{array}$ & $\begin{array}{r}2.62 \\
2.45 \\
3.41 \\
5.28 \\
9.57 \\
18.66\end{array}$ & $\begin{array}{r}8.3288 \\
9.0770 \\
14.9949 \\
22.9189 \\
28.8951 \\
29.7659\end{array}$ & $\begin{array}{l}0.0091 \\
0.0086 \\
0.0124 \\
0.0210 \\
0.0376 \\
0.0636\end{array}$ & $\begin{array}{r}238.9 \\
133.4 \\
26.4 \\
32.8 \\
38.4 \\
42.7 \\
512.6\end{array}$ & $\begin{array}{r}46.6 \\
26.0 \\
5.2 \\
6.4 \\
7.5 \\
8.3 \\
100.0\end{array}$ & $\begin{array}{r}21.8 \\
24.4 \\
27.1 \\
17.2 \\
8.1 \\
12.0 \\
12.0\end{array}$ & $\begin{array}{l}0.0585 \\
0.0536 \\
0.0323 \\
0.0210 \\
0.0166 \\
0.0161\end{array}$ & $\begin{aligned} 6.30 & \pm 0.65 \\
6.60 & \pm 0.70 \\
10.23 & \pm 3.40 \\
10.07 & \pm 3.77 \\
8.69 & \pm 5.20 \\
24.97 & \pm 1.78\end{aligned}$ & 10/7/35 Ddbd & $44^{\prime \prime} 39^{\prime} 23^{\prime \prime}$ & $121^{\prime \prime} 56^{\prime} 56^{\prime \prime}$ \\
\hline$N P-826-P$ & Tis & 0.005564 & - & 26.46 & $\begin{array}{r}825 \\
900 \\
940 \\
1000 \\
1025 \\
1050 \\
\text { FUSE } \\
\text { Total }\end{array}$ & $\begin{array}{l}5.85 \\
3.42 \\
3.19 \\
3.17 \\
3.83 \\
5.14 \\
4.70\end{array}$ & $\begin{array}{r}6.7180 \\
5.6900 \\
5.1220 \\
4.9430 \\
5.3640 \\
4.2900 \\
12.8200\end{array}$ & $\begin{array}{l}0.0106 \\
0.0044 \\
0.0036 \\
0.0040 \\
0.0058 \\
0.0100 \\
0.0101\end{array}$ & $\begin{array}{r}179.7 \\
304.2 \\
203.7 \\
120.0 \\
59.7 \\
83.4 \\
63.0 \\
1013.7\end{array}$ & $\begin{array}{r}17.7 \\
30.0 \\
20.1 \\
11.8 \\
5.9 \\
8.2 \\
6.2 \\
100.0\end{array}$ & $\begin{array}{l}55.2 \\
74.7 \\
78.3 \\
74.5 \\
65.8 \\
48.7 \\
57.6\end{array}$ & $\begin{array}{l}0.0726 \\
0.0857 \\
0.0953 \\
0.0988 \\
0.0910 \\
0.1139 \\
0.0379\end{array}$ & $\begin{array}{l}32.28 \pm 0.41 \\
25.57 \pm 0.31 \\
25.01 \pm 0.42 \\
23.68 \pm 0.40 \\
25.23 \pm 1.37 \\
25.03 \pm 0.99 \\
27.25 \pm 0.99\end{array}$ & $9 / 5: 35 \mathrm{Cdac}$ & $44^{\circ} 44^{\prime} 34^{\prime \prime}$ & $122^{\prime \prime} 09^{\prime} 40^{\prime \prime}$ \\
\hline
\end{tabular}

\section{REFERENCES CITED}

Allen, J.E., 1966, The Cascade Range volcano-tectonic depression of Oregon, in Benson, G.T., ed., Lunar Geological Field Conference, Bend, Oregon, August 1965, Transactions: Oregon Department of Geology and Mineral Industries Open-File Report 0-66-1, p. 21-23.

Beget, J.E., 1982, Pleistocene pyroclastic deposits from eruptions of Mount Jefferson, Oregon [abs.]: American Quaternary Association, National Conference, Abstracts, v. 7, p. 67.

Black, G.L., Woller, N.M., and Ferns, M., 1987, Geologic map of the Crescent Mountain area, Linn County, Oregon: Oregon Department of Geology and Mineral Industries, Geological Map Series GMS-47, scale $1: 62,500$.

Blackwell, D.D., Black, G.L., and Priest, G.R., 1981, Geothermal-gradient data for Oregon (1980): Oregon Department of Geology and Mineral Industries Open-File Report 0-81-3C, 374 p.

- -1986 , Geothermal-gradient_date-for Oregon (1982-1984): Oregon Department of Geology and Mineral Industries Open-File Report O86-2,-107 $\mathrm{p}$

Blackwell, D.D., Bowen, R.G., Hull, D.A., Riccio, J.F., and Steele, J.L., 1982, Heat flow, are volcanism, and subduction in northern Oregon: Journal of Geophysical Research, v. 87, no. B10, p. 8735-8754.

Blackwell, D.D., Hull, D.A., Bowen, R.G., and Steele, J.L., 1978, Heat flow of Oregon: Oregon Department of Geology and Mineral Industries Special Paper 4, $42 \mathrm{p}$.

Clayton, C.M., 1976, Geology of the Breitenbush Hot Springs area, Cagcade Range, Oregon: Portland, Oreg., Portland State University master's thesis, $79 \mathrm{p}$.

Fiebelkorn, R.B., Walker, G.W., MacLeod, N.S., McKee, E.H., and Smith, J.G., 1982, Index to K-Ar age determinations for the State of Oregon: U.S. Geological Survey Open-File Report 82-596, 40 p. Ialso 1983 Isochrop/West, no. 37, p. 3-60].
Hammond, P.E., Anderson, J.L., ard Manning, K.J., 1980, Guide to the geology of the upper Clarkamas and North Santiam Rivers area, northern Oregon Casecte Range, in Oles, K.F., Johnson, J.G., Niem, A.R., and Niem, W.A., eds., Geologic field trips in western Oregon and southwostern Washington: Oregon Department of Geology and Mineral Inidistries Bulletin 101, p. 133-16?

Hammond, P.E. reyer, K.M, and Anderson, J.L. 150́2, Preliminary geologic map and cross sections of the upper Clackamas and North Santiam Rivers area, northern Oregon Cascade Range: Portland, Oreg., Portland State University Department of Earth Sciences, scale $1: 62,500$.

Harland, W.B., Cox, A., Llewellyn, P.G., Pickton, C.A.G., Smith, A.G., Walters, R., and Fancett, K.E., 1982, A geologic time scale: Cambridge, United Kingdom, Cambridge University Press, 131 p.

Laursen, J.M., and Hammond, P.E., 1978, Summary of radiometric ages of Oregon rocks-Supplement 1: July 1972 through December 1976: Isochron/West, no. 23, p. 3-28.

Mariner, R.H., 1985, Geochemical features of Cascades hydrothermal systems, in Guffanti, M., and Muffler, L.J.P., eds., Proceedings of the workshop on geothermal resources of the Cascade Range: U.S. Geological Survey Open-File Report 85-521, p. 59-62.

Palmer, A.R., 1983, The Decade of North American Geology 1983 geologic time scale: Geology, v. 11, no. 9, p. 503-504.

Peck, D.L., Griggs, A.B., Schlicker, H.G., Wells, F.G., and Dole, H.M., 1964, Geology of the central and northern parts of the Western Cascade Range in Oregon: U.S. Geological Survey Professional Paper $449,56 \mathrm{p}$.

Priest, G.R., 1985, Geothermal exploration in Oregon, 1984: Oregon Geology, v. 47 , no. 6 , p. $63-66,69$. 
Priest, G.R., and Woller, N.M.; 1982, Preliminary geology of the Outerson Mountain-Devils Creek area, Marion County, Oregon, in Priest, G.R., and Vogt, B.F., eds., Geology and geothermal resources of the Cascades, Oregon: Oregon Department of Geology and Mineral Indus. tries Open-File Report 0-82-7, p. 71-91.

- - 1983, Preliminary geology of the Outerson Mountain-Devils Creek area, Marion County, Oregon, in Priest, G.R., and Vogt, B.F., eds., Geology and geothermal resources of the central Oregon Cascade Range: Oregon Department of Geology and Mineral Industries Special Paper 15, p. 29-38.

Priest, G.R., Woller, N.M., Black, G.L., and Evans, S.H., 1982, Overview of the geology and geothermal resources of the central Oregon Cascades, in Priest, G.R., and Vogt, B.F., eds., Geology and geothermal resources of the Cascades, Oregon: Oregon Department of Geology and Mineral Industries Open-File Report 0-82-7, p. 5-70.

- 1983 , Overview of the geology of the central Oregon Cascade Range, in Priest, G.R., and Vogt, B.F., eds., Geology and geothermal resources of the central Oregon Cascade Range: Oregon Department of Geology and Mineral Industries Special Paper 15, p. 3-28.

Rollins, A., 1976, Geology of the Bachelor Mountain area, Linn and Marion Counties, Oregon: Corvallis, Oreg., Oregon State University master's thesis, $83 \mathrm{p}$.
Sutter, J.F., 1978, K-Ar ages of Cenozoic volcanic rocks from the Oregon Cascades west of 121 ${ }^{\circ 30}$ ': Isochron/West, no. 21, p. 15-21.

Taylor, E.M., 1980, Volcanic and volcaniclastic rocks on the east flank of the central Cascade Range to the Deschutes River, Oregon, in Oles, K.F., Johnson, J.G., Niem, A.R., and Niem, W.A., eds., Geologic field trips in western Oregon and southwestern Washington: Oregon Department of Geology and Mineral Industries Bulletin 101, p. 1-7.

Thayer, T.P., 1939, Geology of the Salem Hills and the North Santiam River basin, Oregon: Oregon Department of Geology and Mineral Industries Bulletin 15, $40 \mathrm{p}$.

Walker, G.W., MacLeod, N.S., and Blakely, R.J., 1985, Mineral resource potential of the Bull of the Woods Wilderness, Clackamas and Marion Counties, Oregon: U.S. Geological Survey Open-File Report 85-247, 28 p.

White, C.M., 1980a, Geology and geochemistry of volcanic rocks in the Detroit area, Western Cascade Range, Oregon: Eugene, Oreg., Univer. sity of Oregon doctoral dissertation, $178 \mathrm{p}$

- $-1980 \mathrm{~b}$, Geology of the Breitenbush Hot Springs quadrangle, Oregon: Oregon Department of Geology and Mineral Industries Special Paper 9, 26 p.

\section{DISCLAIMER}

This report was prepared as an account of work sponsored by an agency of the United States Government. Neither the United States Government nor any agency thereof, nor any of their employees, makes any warranty, express or implied, or assumes any legal liability or responsibility for the accuracy, completeness, or usefulness of any information, apparatus, product, or process disclosed, or represents that its use would not infringe privately owned rights. Refer: ence herein to any specific commercial product, process, or service by trade name, trademark, manufacturer, or otherwise does not necessarily constitute or imply its endorsement, recommendation, or favoring by the United States Government or any agency thereof. The views and opinions of authors expressed herein do not necessarily state or reflect those of the United States Government or any agency thereof. 


\section{LEGIBILITY NOTICE}

A major purpose of the Technical Information Center is to provide the broadest possible dissemination of information contained in DOE's Research and Development Reports to business, industry, the academic community, and federal, state, and local governments. Non-DOE originated information is also disseminated by the Technical Information Center to support ongoing DOE programs.

Although large portions of this report are not reproducible, it is being made available only in paper copy form to facilitate the availability of those parts of the document which are legible. Copies may be obtained from the National Technical Information Service. Authorized recipients may obtain a copy directly from the Department of Energy's Technical Information Center.

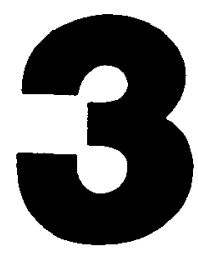



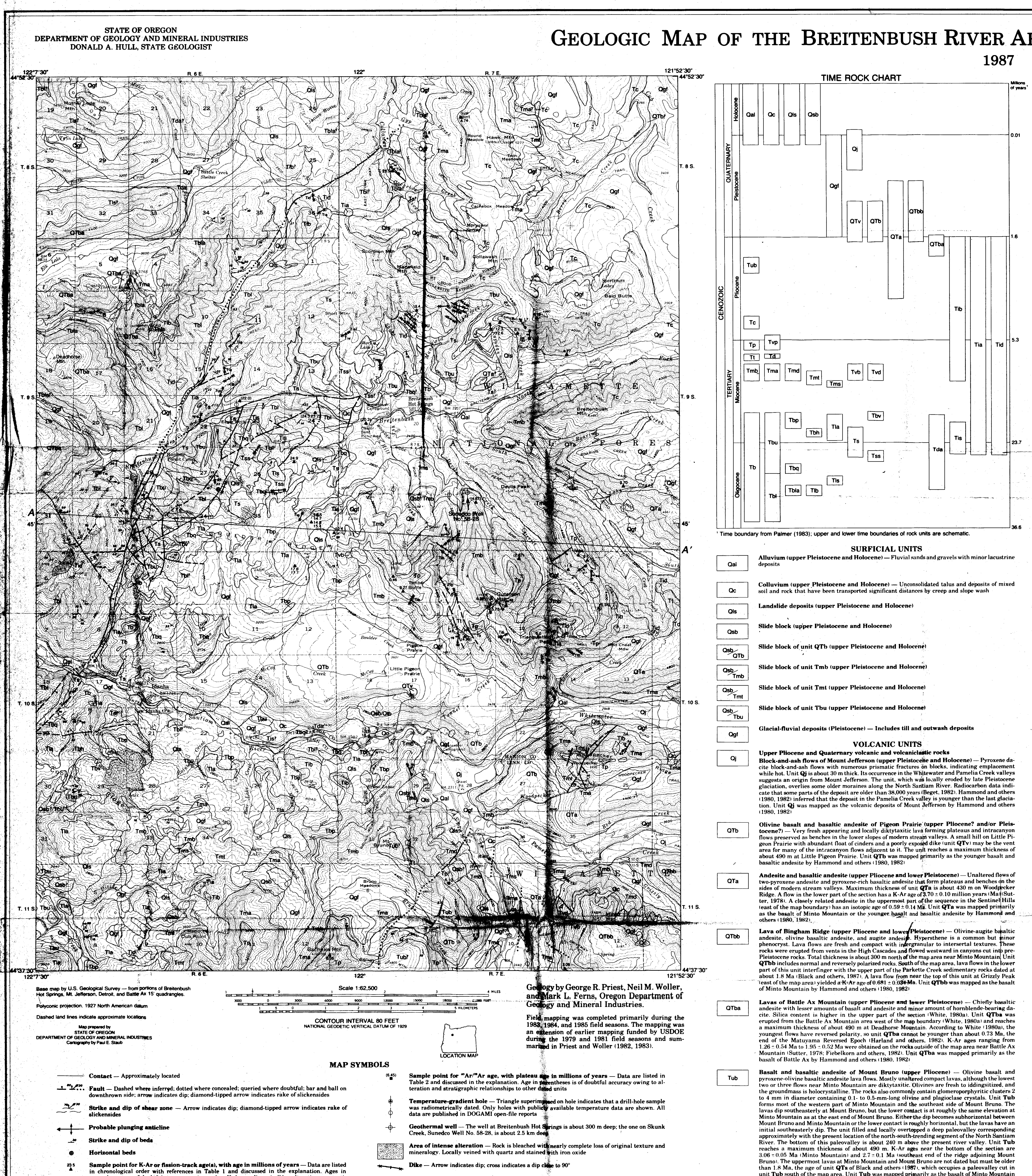

$=$

$=$

Coolocil CRoss SECTION

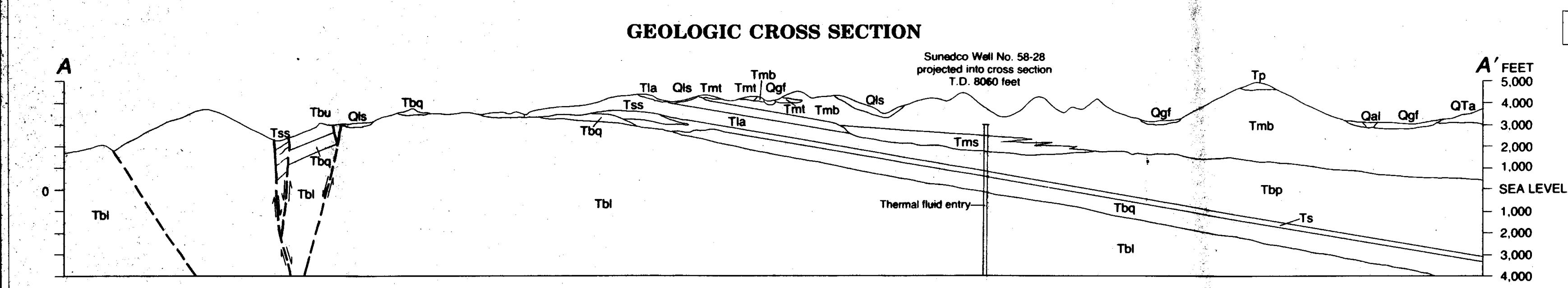

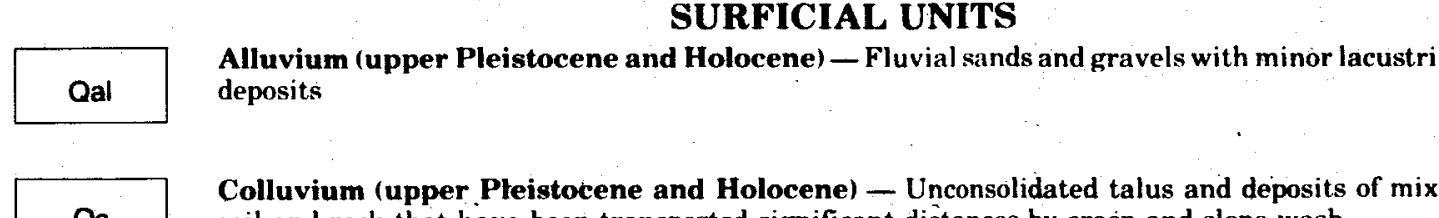

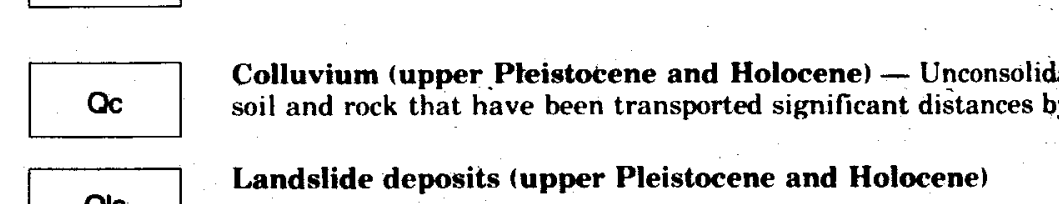

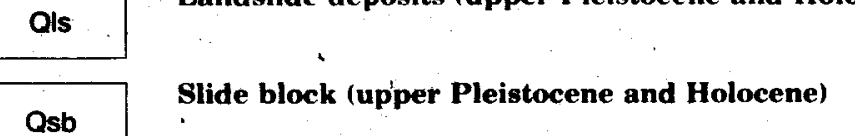

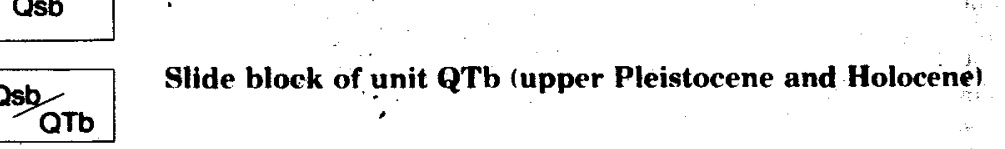

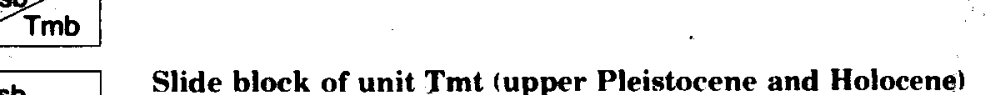

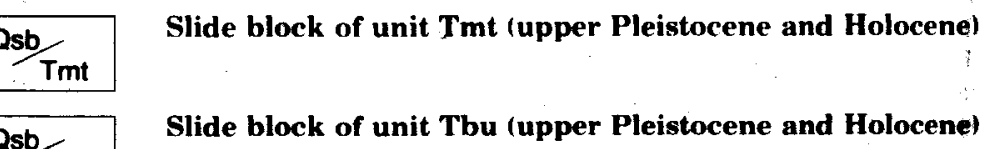

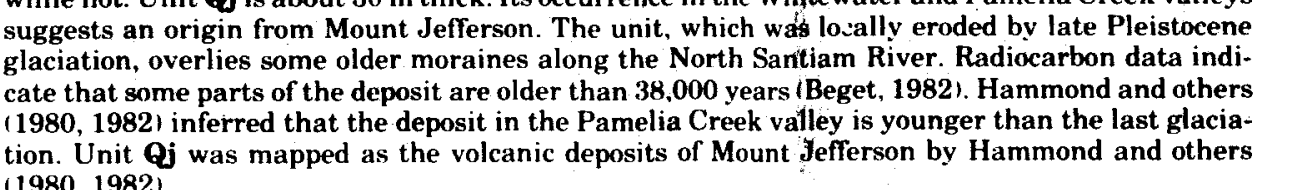

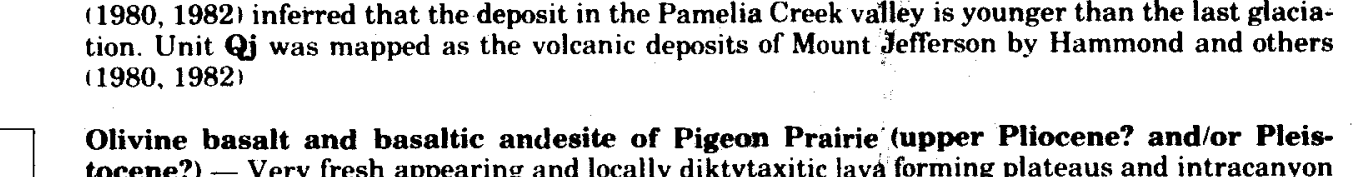

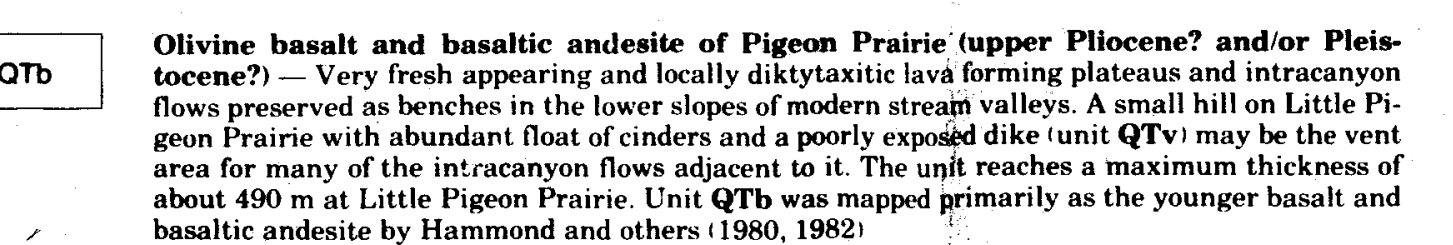

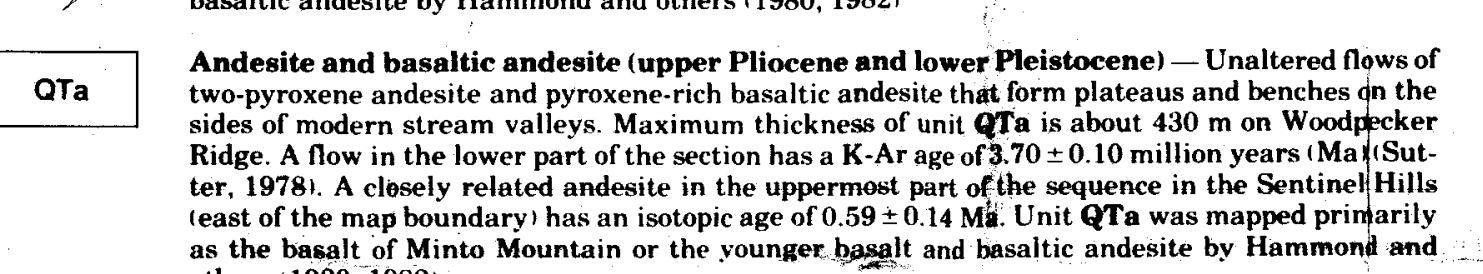

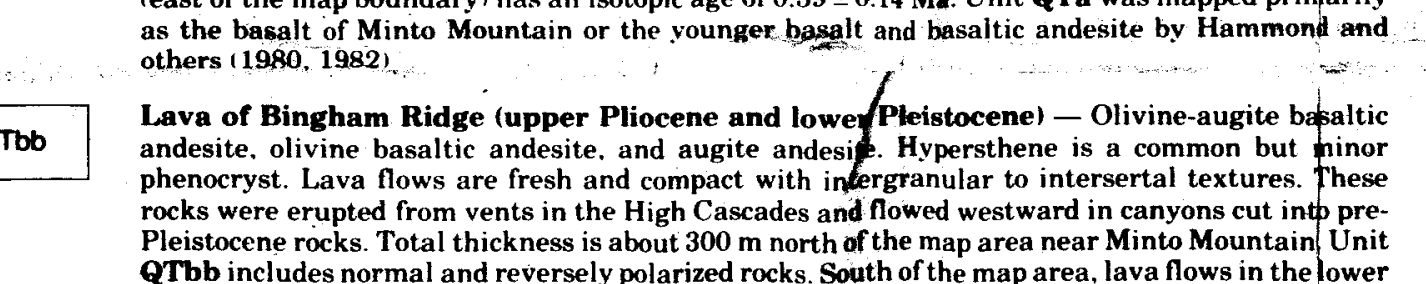

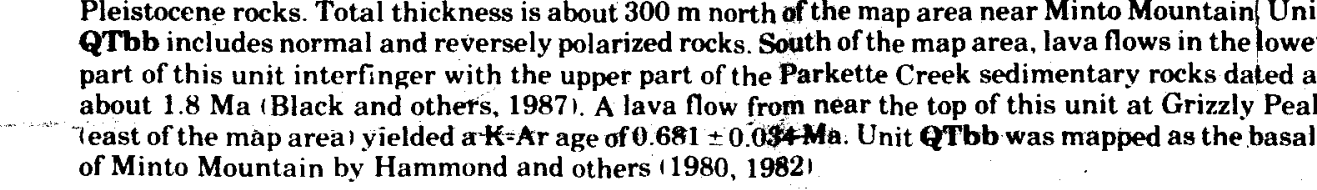

oriag

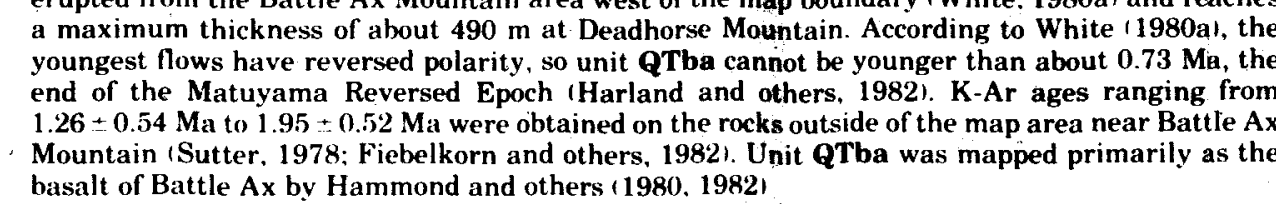

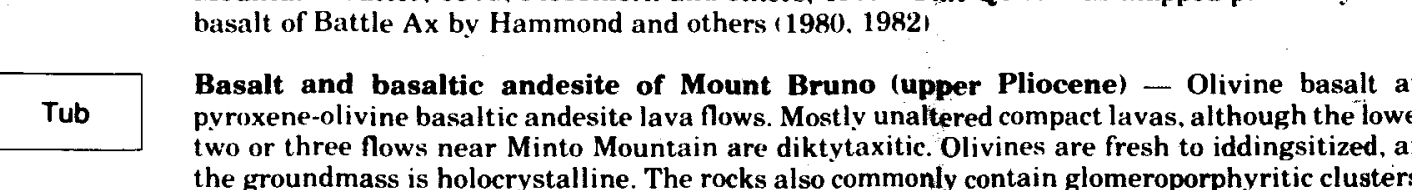

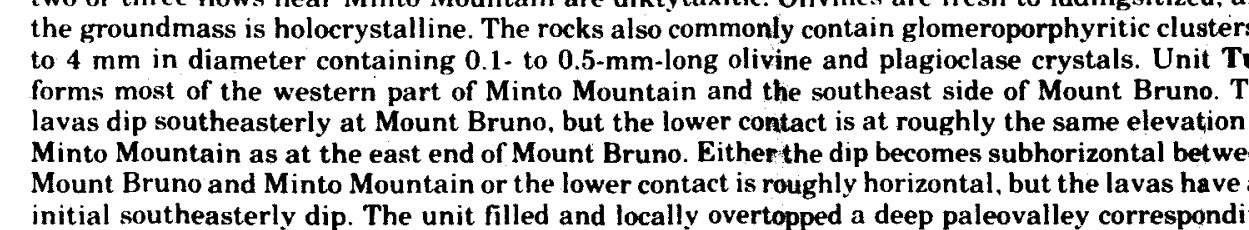

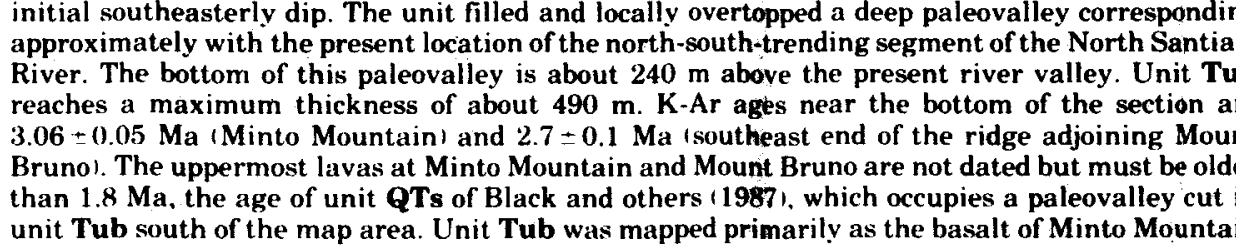

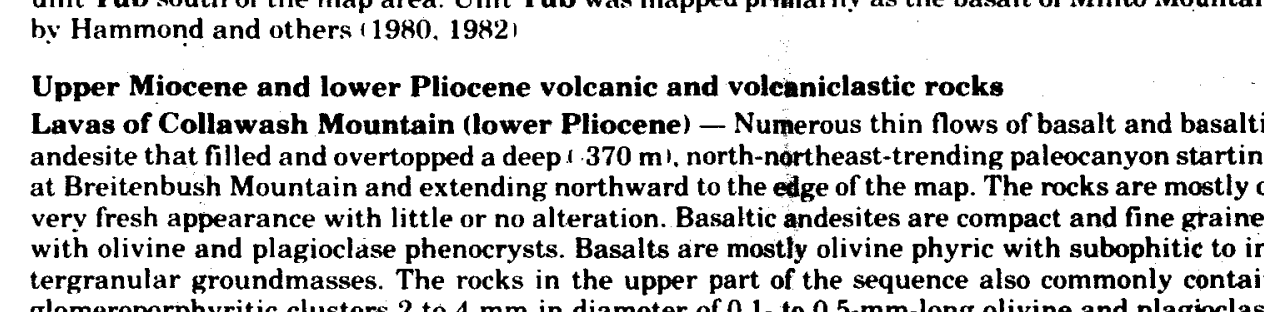

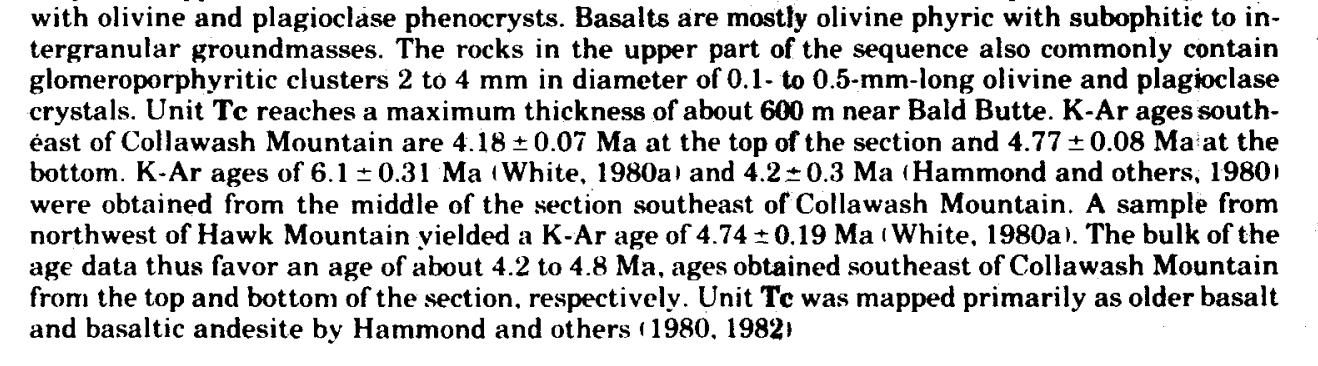

Tow

Q
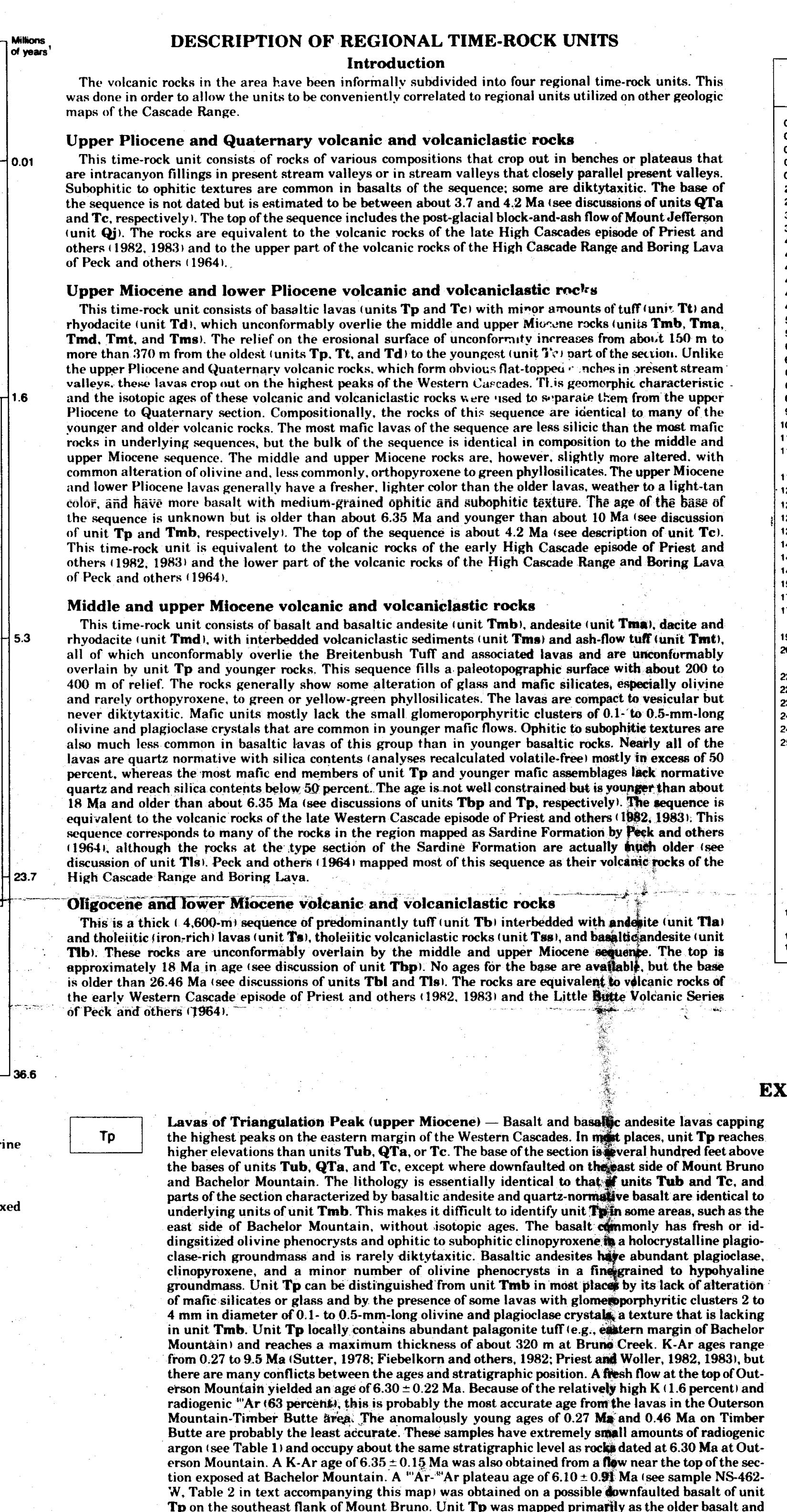

Tring

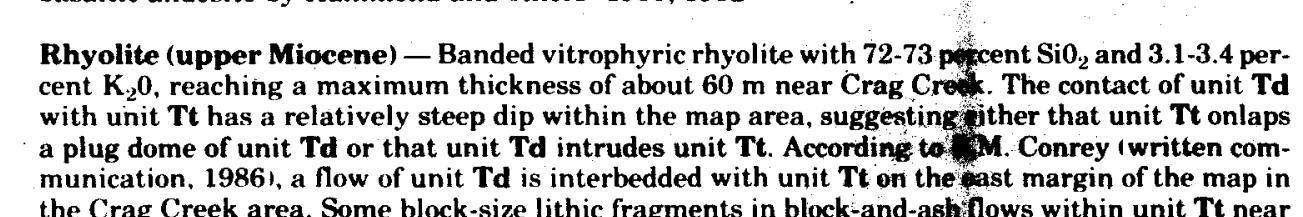

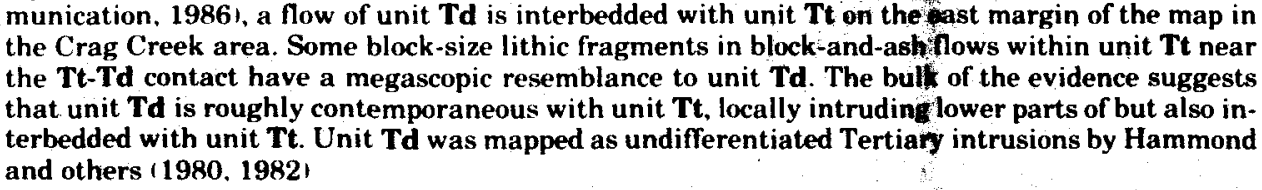

$n \rightarrow$

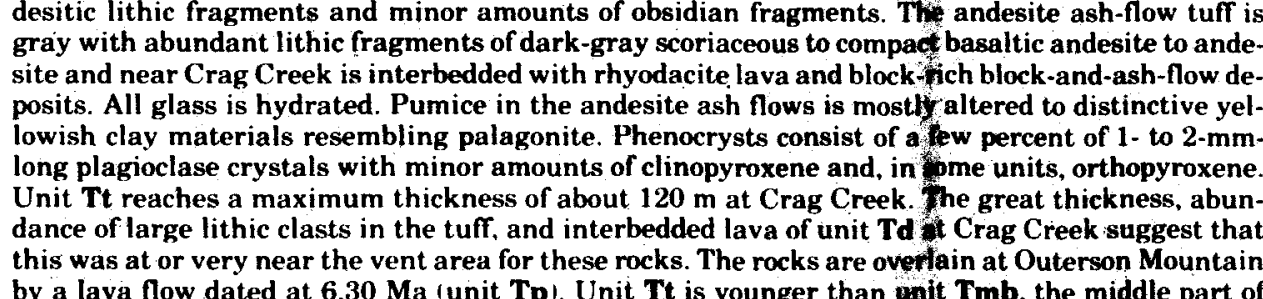

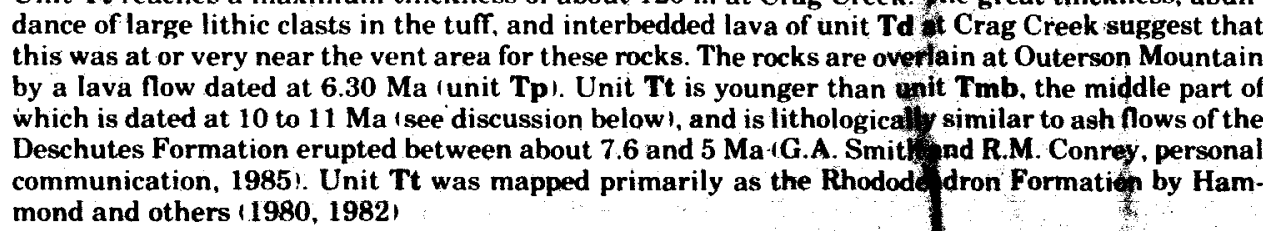

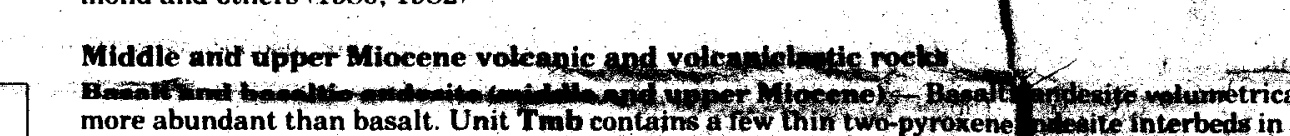

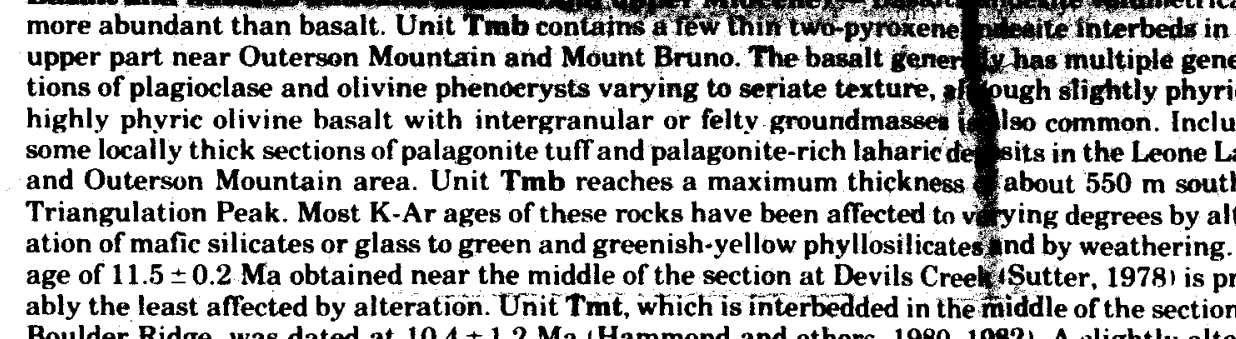

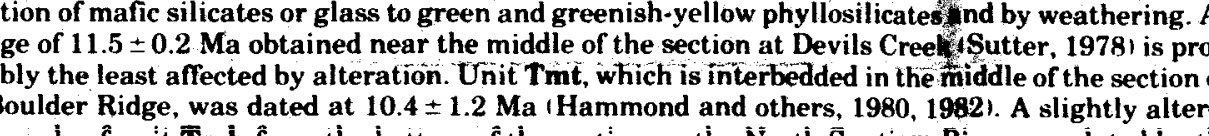

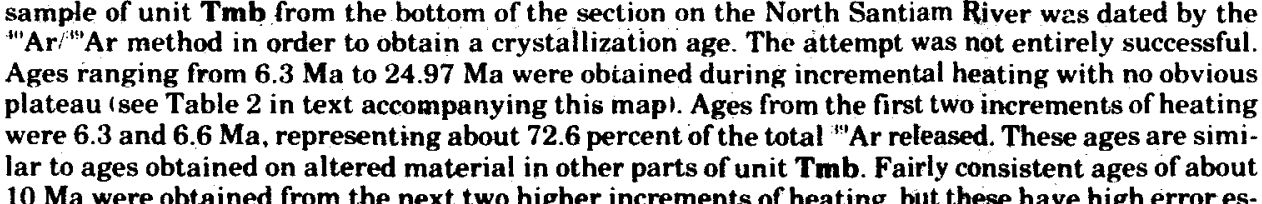

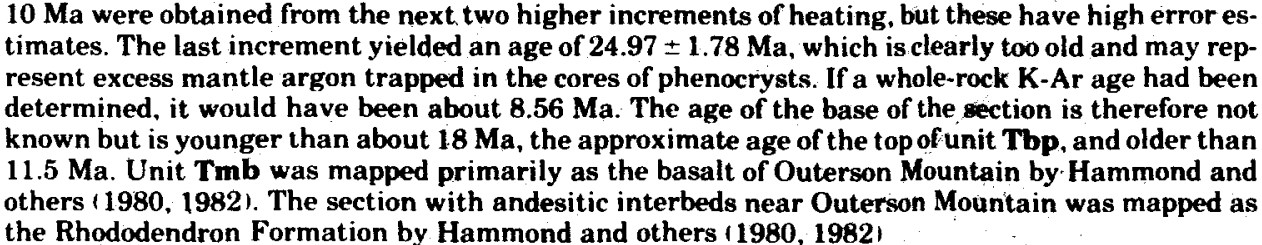

trat

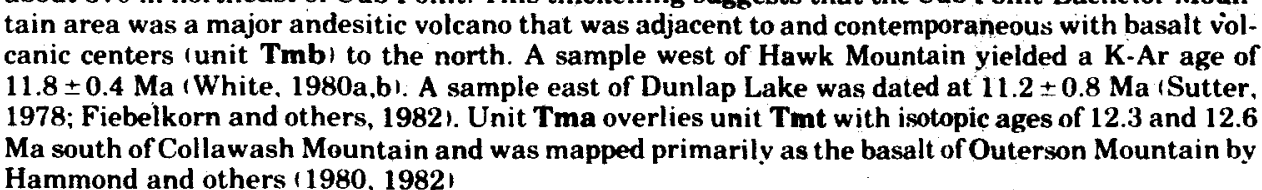

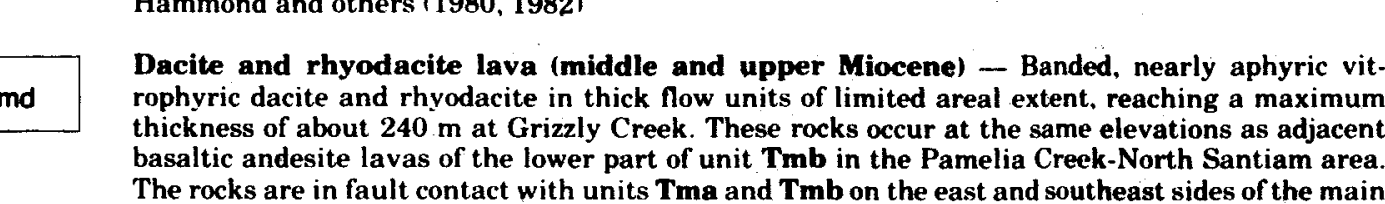

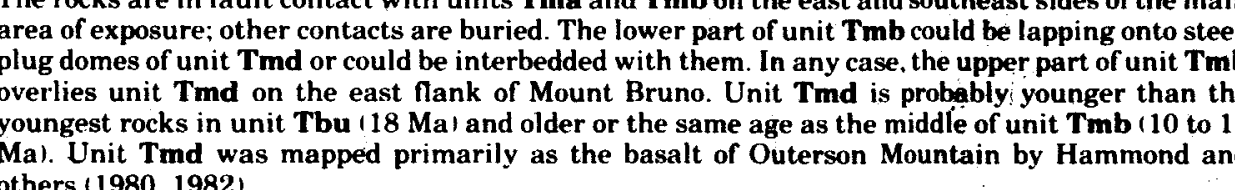

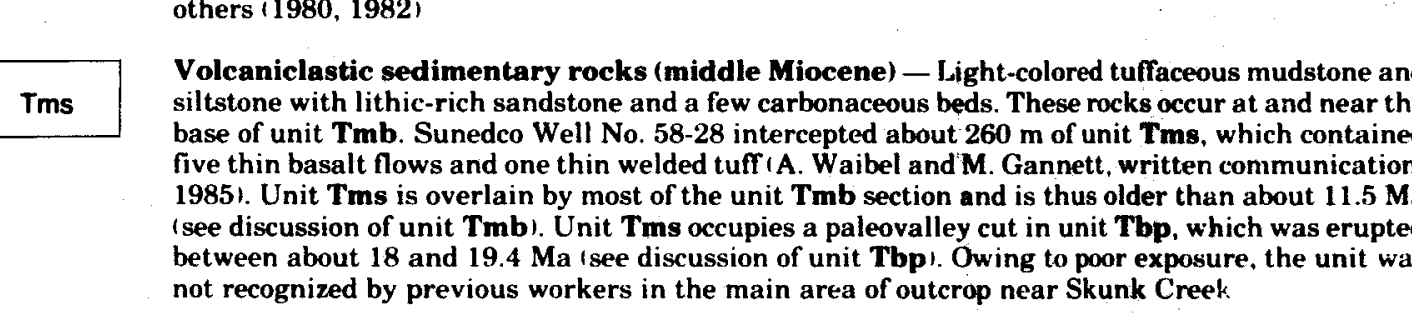

(i)

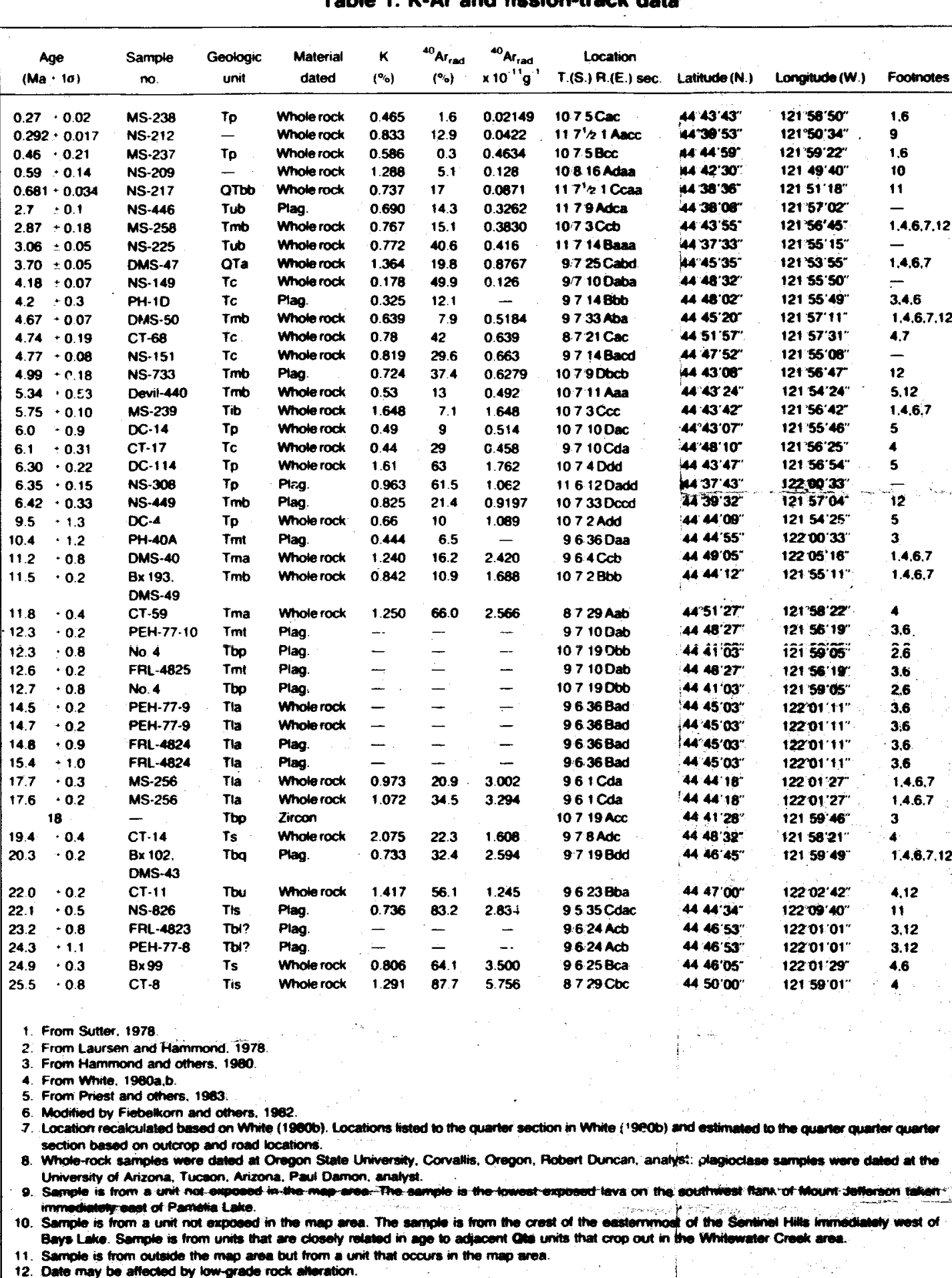

XPLANATION

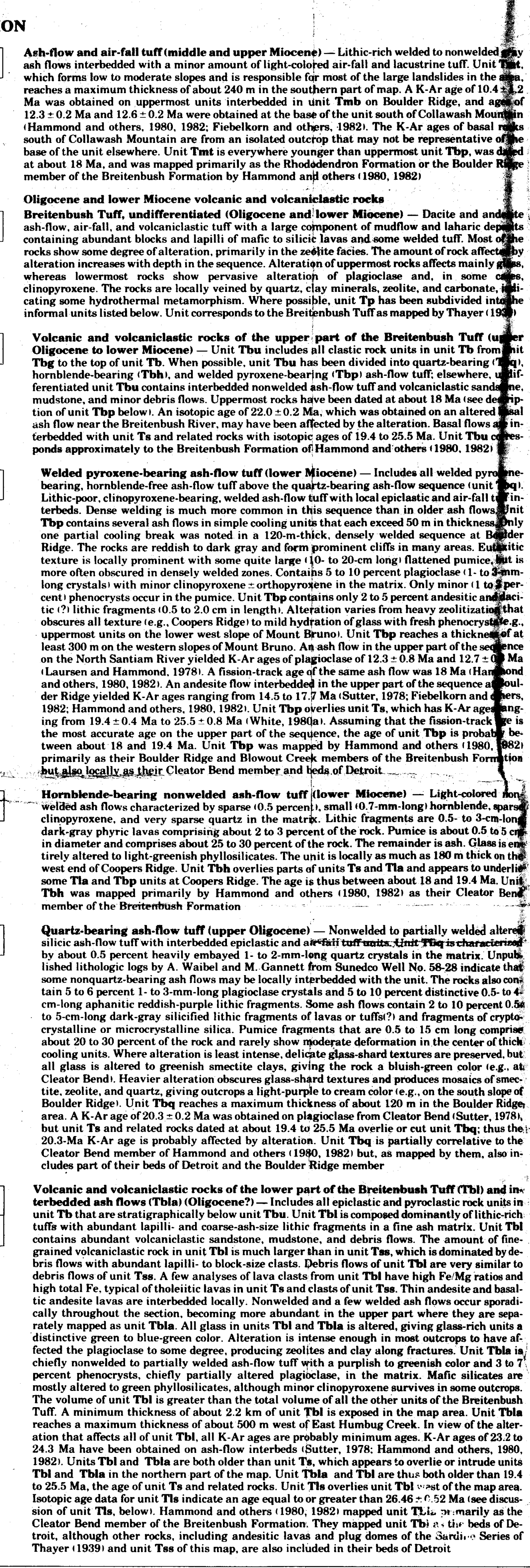

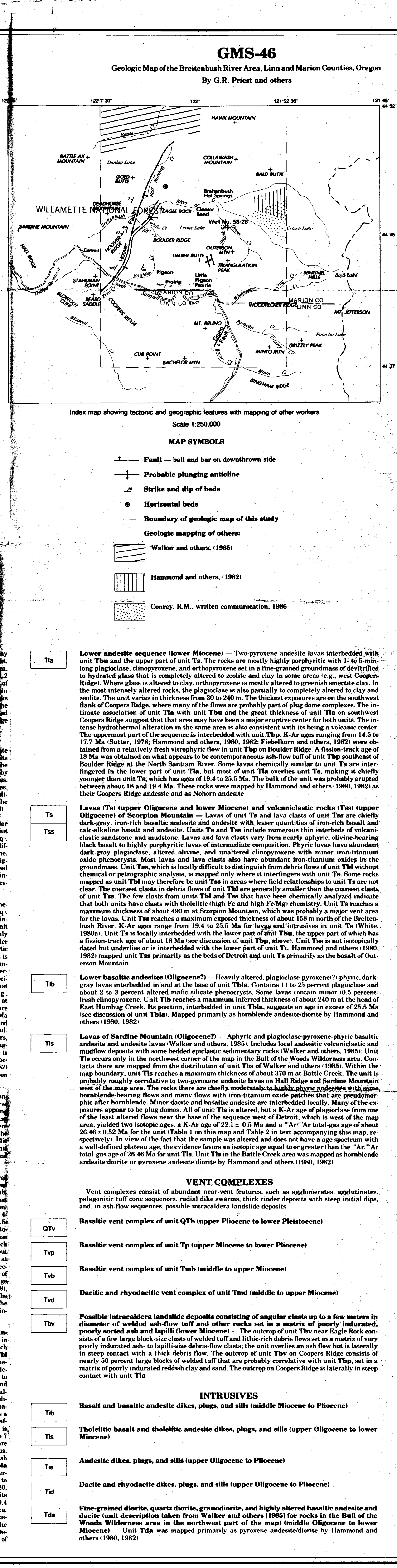

